\title{
Estudios iconológicos en la prensa ilustrada del siglo XIX. El Album de la guerra de Paraguay y la visualidad de "lo igualmente visible"*
}

\section{ICONOLOGICAL STUDIES IN NINETEENTH-CENTURY ILLUSTRATED NEWSPAPERS. THE ALBUM OF THE PARAGUAYAN WAR AND THE VISUALITY OF "THE EQUALLY VISIBLE"}

ESTUDOS ICONOLÓGICOS NA PRENSA ILUSTRADA NO SÉCULO XIX. O ÁLBUM DA GUERRA DO PARAGUAI E A VISUALIDADE "DO IGUALMENTE VISÍVEL"

\section{Sebastián Díaz-Duhalde**}

Cuadernos de Música, Artes Visuales y Artes Escénicas / Volumen 9 - Número 2 / julio - diciembre de 2014 / ISSN 1794-6670/ Bogotá, D.C., Colombia / pp. 127-146

Fecha de recepción: 19 de mayo de 2014 | Fecha de aceptación: 15 de julio de 2014. Encuentre este artículo en http://cuadernosmusicayartes.javeriana.edu.co/

doi:10.11144/Javeriana.mavae9-2.eipi

* El presente artículo corresponde a la investigación de Estudios Iconológicos y límites de la representación en revistas ilustradas de guerra en el Cono Sur durante el siglo XIX.

* Profesor en el Departamento de Español y Portugués en Dartmouth College. 


\section{Resumen}

A principios de 1893 la revista Álbum de la guerra del Paraguay dio sus primeros pasos en la prensa ilustrada argentina. El Álbum, que pretendía iluminar los eventos del conflicto de la Triple Alianza contra Paraguay (1864-1870) a través de testimonios de los combatientes, se convirtió en uno de los archivos visuales y textuales más grandes sobre el enfrentamiento bélico. El propósito del presente trabajo es explorar la representación de la guerra a través del análisis de las relaciones iconológicas de la publicación (interacciones entre el

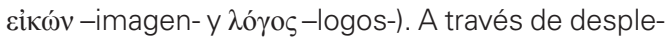
gar un arreglo visual en el que las imágenes y los textos se tornan igualmente visibles e igualmente legibles, sugiero que el Álbum se presenta como una nueva forma de comprender los límites de las representaciones bélicas en el cierre del siglo XIX

Palabras clave: Álbum de la guerra del Paraguay; iconología; cultura visual; siglo XIX Latinoamérica; guerra del la Triple Alianza; archivo de la guerra

\section{Abstract}

At the beginning of 1893 the illustrated newspaper Álbum de la guerra del Paraguay made its first appearance in the Argentinean visual media arena. The Álbum tried to illuminate the events of the war that the war events that took place during the Paraguayan War (1864-1870), through the testimonies of soldiers who bore witness to the destruction of the country. Organized as a heterogeneous collection of images and texts, it became one of the biggest visual and textual archives of the international conflict. Via an iconological analysis, in this article I explore the relationship between visual and textual regimens of war representation. By deploying a visual arrangement in which texts and images are equally visible, equally legible (i.e. the visuality of the "equally visible"), I claim that the Álbum leads us towards a new way of understanding the limits of war representation at the end of the nineteenth century.
Keywords: Álbum de la guerra del Paraguay; iconology; visual culture; nineteenth-century Latin America; Paraguayan War; war archive

\section{Resumo}

Nos inicios de 1893 o jornal ilustrado Álbum de la guerra del Paraguay aparece na prensa argentina. O Álbum que pretendia iluminar os acontecimentos do conflito entre a Tríplice Aliança contra o Paraguai (1864-1870) mediante testemunhos dos participantes, transformo-se em uno dos maiores acervos visuais e escritos do enfrentamento bélico. Nessas paginas exploro a representação da guerra a traves do analises das relações iconológicas na publicação (as interações entre દỉkóv e $\lambda$ '́үos). Ao mostrar o arregro visual onde as imagens e os textos tornam-se igualmente visíveis, sugiro que o Álbum presenta-se como a nova forma de compreender os limites das representações bélicas ao fim do século XIX.

Palavras-chaves: Álbum de la guerra del Paraguay; iconología; estudos visuais; século XIX América Latina; Guerra do Paraguai; arquivo da guerra 


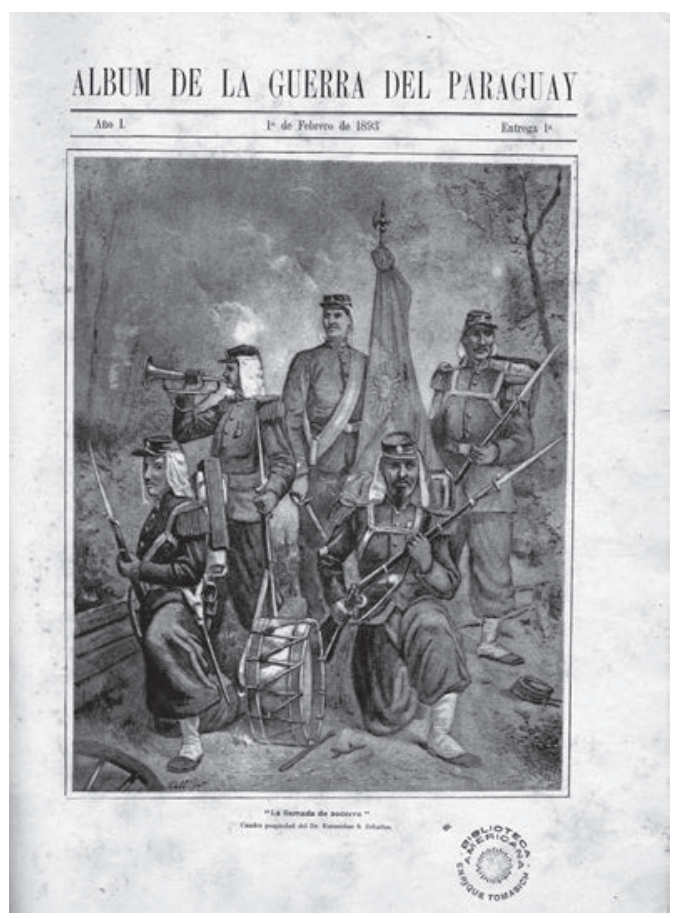

Imagen 1. Álbum de la guerra del Paraguay. Tapa de Entrega No1. 1893, p.1.

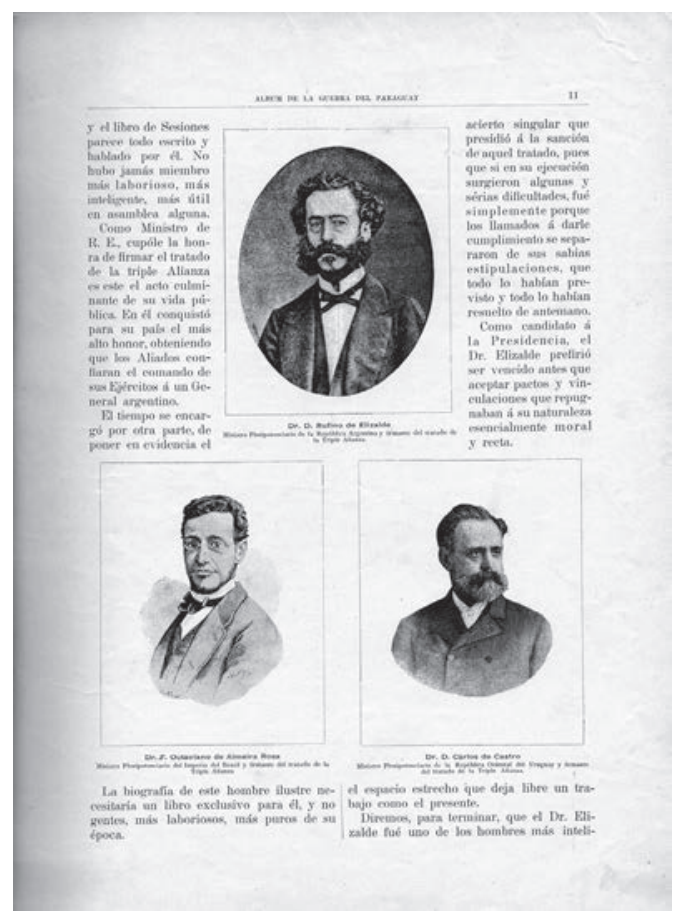

Imagen 2. Álbum de la guerra del Paraguay. 1893, p.11.

Veintitrés años después de la finalización de la guerra entre la Triple Alianza de Argentina, Uruguay y el Imperio del Brasil contra Paraguay (1864-1870), la asociación de ex combatientes argentinos (Asociación de Guerreros del Paraguay) lanza el primer número del Álbum de la guerra del Paraguay. Según su director y editor, el comandante de artillería Juan José Soto, el proyecto "no pretendía hacer historia" (Álbum, 1893, p. 6) sino que se constituía como un ejercicio de acumulación de fuentes en la prensa periódica. De este modo, afirma Soto que

(...) el Álbum pretende coleccionar en forma de galería los retratos de los que actuaron, las armas que usaron, los uniformes que vistieron, los elementos de movilidad de que se disponía en aquella época, la vista por decirlo así pintoresca de los campamentos que ocuparon, de las fortificaciones que atacaron o defendieron, los esteros, las selvas, los ríos que se cruzaron (...) que servirán de antecedentes, de información y de consulta al biógrafo o al historiador que presente a las generaciones del porvenir el cuadro completo de aquella guerra. (1893, p. 2, la cursiva es énfasis mío)

La revista ilustrada acumula entonces en sus tres años de existencia y sus 45 entregas (1893-1896) más de 600 imágenes de la guerra y 223 biografías de soldados junto con piezas de ficción, anécdotas del frente, cartas, partes oficiales de batalla y cientos de testimonios de la lucha entre los países, convirtiéndose así en la colección visual y textual más grande del conflicto existente en la actualidad.

El Álbum nunca intenta generar un texto capaz de ordenar la fragmentación, ni propone un aparato de montaje para unir lo disímil, para conciliar la segmentación o soldar la fractura del contenido de sus páginas. Como lo indica Soto: 
Creo que la historia de la guerra del Paraguay todavía no está escrita en todos sus detalles.

Esta lucha gigantesca de cuatro naciones jóvenes no ha encontrado aún su historiador y pasará algún tiempo antes que este tremendo drama sea conocido en todas sus partes. (1893, p. 3)

Quedan así imágenes y textos librados a una causa ausente que los pondrá a funcionar en un discurso histórico futuro y que los sostiene desde dicha ausencia y desde la esperanza del porvenir. Sin embargo, dos dinámicas visuales enraizadas en la cultura finisecular disponen de modo subyacente el arreglo de las imágenes y los textos de la publicación: la "galería" como un espacio de orden y regulación de la mirada, y el "álbum" que avala en la formación de una colección íntima la heterogeneidad de objetos. Ambas dinámicas no solo establecen las coordenadas de la acumulación documental, sino que, al mismo tiempo, generan un orden que permite hacer visible y legible a la guerra contra Paraguay.

En este artículo indagaré de qué modo en su despliegue iconológico el Álbum de la guerra del Paraguay indica una nueva forma de representación de la historia de la guerra. Esto es, explorar a través de las relaciones entre la imagen y el texto cómo esta revista ilustrada comienza a mostrar y a contar una historia diferente sobre el conflicto armado. Intentaré pensar dicha representación visual y textual a la luz de lo que el teórico francés Jacques Rancière llama la visualidad de "lo igualmente visible" (2007, pp. 120-121), como una narrativa propia del siglo XIX en la que todos los eventos pierden proporción y jerarquía tornándose "igualmente representables". Esta es solamente una de las múltiples claves de lectura que creo relevantes para analizar las relaciones iconológicas. Asimismo, es una de las maneras más fértiles para explorar la prensa ilustrada del siglo en tanto se configura a sí misma como "documento" o como colección documental para la historia.

Estas páginas son entonces una oportunidad para reflexionar sobre las imágenes en tanto pertenecen a un régimen de representación de naturaleza mixta (visual y textual). En este sentido, mi análisis se ve enmarcado por los estudios iconológicos que se encargan de formu-

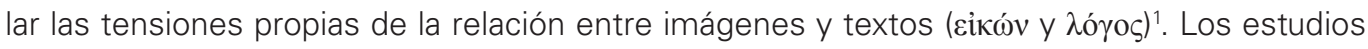
iconológicos en la academia norteamericana pasan de estar gravitando en las órbitas discursivas de la historia del arte a pertenecer al discurso interdisciplinario de lo que hoy se conoce como estudios de cultura visual. Esta incorporación se da paulatinamente desde que W.J.T. Mitchell en 1995 comenzó a tratar los "estudios visuales" (o estudios de cultura visual) como un nombre para la confluencia entre la historia del arte, los estudios culturales y la teoría literaria, que terminarían marcando lo que él mismo denominó como "giro pictórico"2.

La división entre imágenes y textos ha sido un lugar frecuente en la partición de la representación, esto es, en la distinción entre modos de expresión verbal y visual. Según señala Mitchell, esta división encierra también un topos cultural cuyas connotaciones exceden las diferencias formales o estructurales entre ambos modos. Por ejemplo, la diferencia entre una cultura de lectores y una de espectadores tiene implicaciones en la generación de pautas de sociabilidad y subjetividad $(1995$, p. 3) que señalan un más allá del análisis estructural de la relación. La división entre imagen y texto y sus múltiples traducciones e instanciaciones se presentan como una encrucijada fundamental a la hora de analizar la prensa ilustrada decimonónica latinoamericana. Tradicionalmente la centralidad de la cultura letrada en el siglo XIX formulada y propagada desde los estudios literarios y la crítica cultural a través del trabajo póstumo de Ángel Rama (1984) ha servido de paradigma para el análisis de los medios gráficos del periodo, separando y subsumiendo lo visual a lo textual. Dicha división se encuentra justificada parcialmente desde la metadiscursividad de la disciplina literaria y del estudio de Rama que se 
enfoca en el análisis del rol de la escritura y los intelectuales letrados desde el periodo colonial hasta la formación y consolidación de los Estados nacionales latinoamericanos. Por otro lado, el análisis de la dimensión visual de los medios gráficos en el XIX ha sido también relegado desde la historia del arte que no terminaba de asimilar a la prensa como portadora de una visualidad cercana a la sensibilidad de la pintura decimonónica del continente (Achugar, 2008, pp. 215-216). Debe mencionarse aquí el caso excepcional de la corriente de historiadores del arte paraguayos que desde los años sesenta con Josefina Plá (1962, 1967), pasando por Ticio Escobar $(1982,1984)$ y Osvaldo Salerno $(1984,1998)$ han ubicado a la prensa ilustrada del XIX como portadora de una expresión artística única en el siglo.

No obstante, los estudios de la cultura visual latinoamericana decimonónica han comenzado a pensar la prensa ilustrada desde su dimensión iconológica, es decir, desde la interacción intrínseca entre imágenes y textos. Algunos trabajos ya fundacionales dedicados a la dimensión visual y textual de la prensa del siglo XIX desde un enfoque interdisciplinario son los de González-Stephan (2006, 2009), Andermann (2006), Achugar (2008), Acree (2009), Espitia (2009), Schwarcz (1987, 1998) o Knauss (2011), por ejemplo. Estos ensayos piensan las tensiones propias que una cultura letrada organiza sobre el lugar de la imagen en la segunda mitad del siglo, especialmente en el Cono Sur y el segundo reinado del Imperio de Brasil (1840-1889). Al mismo tiempo, y como aporte interdisciplinar a los estudios de los medios de comunicación, se ha pensado a los periódicos ilustrados como dispositivos visuales modernos sostenidos por e incluidos en los avances tecnológicos de la segunda mitad del siglo XIX. Como sostiene Paulette Silva Beauregard, la prensa ilustrada se presenta como un lugar de exhibición y exposición, como un logro técnico, ya que sus páginas eran la muestra de los avances en materia de impresión, reproducción y en las técnicas de ilustración. Del mismo modo, se los ve como lugares de mediación de una "cultura" visual internacional dado que alternaban la publicación de imágenes y textos de otros medios, hecho que señala una complejísima y desarrollada red de circulación gráfica mundial (2006, p. 373).

De este modo, y dentro de este marco analítico, mi propuesta es entender las relaciones iconológicas establecidas en el Álbum de la guerra del Paraguay considerando esta revista ilustrada como un "galería" y a la vez como un "álbum", como un espacio visual que impone ciertas reglas y procedimientos a través de los que el relato de la guerra contra el Paraguay establece condiciones específicas de legibilidad y visibilidad (ilegibilidad e invisibilidad) de la guerra como un evento. Es decir, considerar la revista como una zona de circulación de dos regímenes visuales que interactúan con el discurso textual afectándose al representar la guerra.

\section{EL ÁLBUM DE LA GUERRA DEL PARAGUAY}

El Álbum de la guerra del Paraguay fue impulsado por la comunidad argentina de veteranos de la guerra conocida como Asociación de Guerreros del Paraguay de la República Argentina $^{3}$. Impresa primero en la Imprenta de Jacobo Peuser y luego en el Taller de Tipografía de la Penitenciaría Nacional, sus páginas recogían testimonios directos de veteranos del conflicto, notas de opinión, anécdotas de campamento e imágenes de todo tipo: retratos de fallecidos durante la guerra y retratos de veteranos célebres en la arena política de sus respectivos países -como el de los presidentes al momento del conflicto Bartolomé Mitre, Venancio Flores, el Emperador Pedro II y Francisco Solano López-, otros de no tan célebres guerreros y 


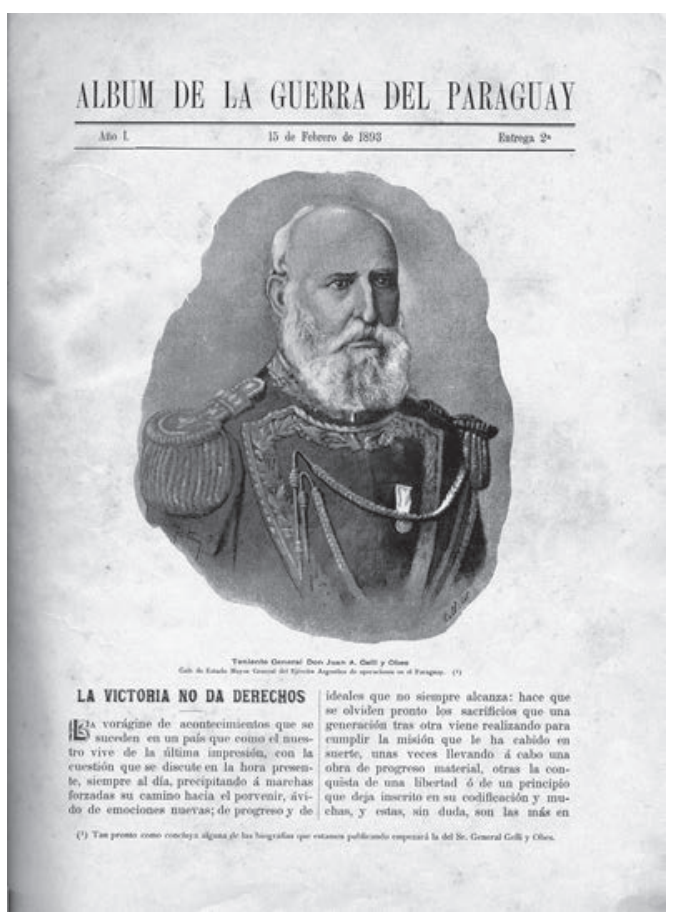

Imagen 3. Álbum de la guerra del Paraguay. Tapa de Entrega №2. 1893, p.17.

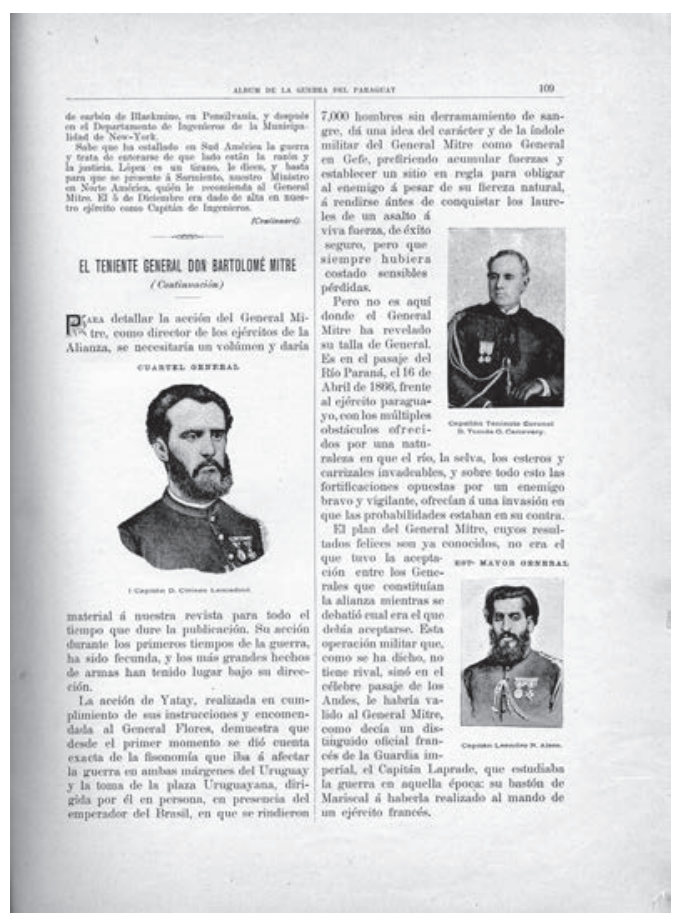

Imagen 4. Álbum de la guerra del Paraguay. 1893, p.109.

la mayoría de ignotos. Incluía también litograbados de pinturas (como las de Cándido López e Ignacio Garmendia), ilustraciones (como las de Methfessel) y fotografías de la guerra. También ocasionalmente contaba con cartografía bélica distribuida a modo de pliego suelto dentro de los diferentes números ${ }^{4}$. En este sentido, el álbum es testigo de la cultura visual producida durante y después del conflicto por sus protagonistas. En sus páginas se publican y publicitan las obras de pintores y grabadores consagrados, así como se legitima el fotoperiodismo como práctica de registro de la realidad bélica en su dimensión más moderna. En total aparecen más de 600 imágenes de guerra, de las cuales 411 son litograbados de retratos fotográficos de soldados ${ }^{5}$. Enviada por suscripción a sus lectores, la mayoría ex combatientes y familiares, el Álbum recibía de estos relatos e imágenes que luego serían incluidos en los 45 números que tuvo durante su existencia. Muchas contribuciones provenían de Uruguay, de Brasil e inclusive de Paraguay. Esta revista ilustrada se conforma así como una colección documental de testimonios visuales y textuales de los casi 6 años de lucha entre los ejércitos de la Triple Alianza y la República del Paraguay y su repercusión en la comunidad de veteranos argentinos. El Álbum apareció a principios de 1893 y circuló hasta 1896, 26 años después de la muerte del mariscal y presidente paraguayo Francisco Solano López el $1^{\circ}$ de marzo de 1870 en Cerro Corá, evento con el que la historiografía suele cerrar la contienda.

A fines de 1864 se inicia la guerra de la Triple Alianza contra Paraguay. El enfrentamiento es también conocido como Guerra Grande, Guerra Guazú, Guerra del 70', guerra del Paraguay o guerra contra el Paraguay. La guerra contra el Paraguay constituye uno de los grandes conflictos del siglo XIX no solo por sus proporciones militares, sino por las consecuencias sociales, políticas y económicas que tuvo en las naciones del Cono Sur ${ }^{6}$. La guerra tiene como antecedentes inmediatos el intento de intervención económica/militar del Imperio brasilero en el Uruguay y el intento del Paraguay por mediar e intentar impedir el avance monopólico imperial 
que, una vez más, amenazaba con controlar el tránsito de mercancías por las vías fluviales -el río Paraná, el río Uruguay y el río de la Plata- que permitían el comercio local y mundial de las cuatro naciones ${ }^{7}$. Las acciones bélicas, que incluyeron la invasión de la Alianza al territorio del Paraguay, provocaron no solo la desaparición de más del $60 \%$ de la población paraguaya, sino también la redistribución de territorios nacionales en la cuenca del Plata y el endeudamiento con potencias ultramarinas de todos los países involucrados. ${ }^{8}$

El Álbum de la guerra del Paraguay no sigue la cronología de eventos del conflicto internacional, ni tiene secciones o divisiones temáticas constantes que ordenen el contenido textual o las imágenes. La heterogeneidad de materiales en sus páginas lo hace una miscelánea abrumadora, a tal punto que cada uno de sus ejemplares tiene forma de colección azarosa de piezas conseguidas en el momento:

Nuestras columnas están abiertas para todos los que quieran transmitir sus impresiones, los hechos de que fueron actores o testigos y se sientan capaces de narrarlas con imparcialidad o con ingenio según se trate de episodios históricos o ficciones literarias. (Álbum, 1893, p. 2)

El producto que surge de esta recolección es fácil de adivinar. La mayoría de sus notas escritas son testimonios que descansan en la memoria e imaginación de los ex combatientes que van a omitir fechas, confundir nombres y agregar datos inventados de algunos episodios históricos. La mayor parte de las imágenes no está tampoco relacionada con los textos: hay, por ejemplo, biografías acompañadas por retratos de distintos soldados no relacionados con el biografiado, o litograbados de soldados que irrumpen en la narrativa de episodios de la guerra, de cuentos o de anécdotas sin formar parte de ninguno de estos.

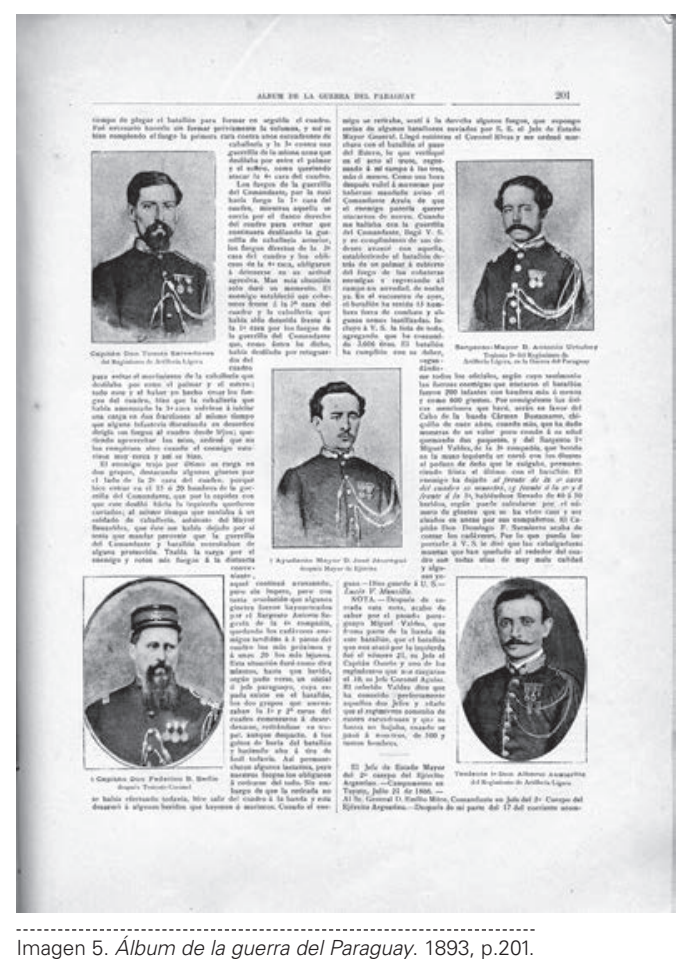

Ahora bien, las imágenes que sí están relacionadas con narrativas textuales están corregidas por un texto que marca la falencia de la representación visual: 
Cuando el original ha desaparecido durante la guerra o después de ella, el hecho no tiene remedio: de algunas personas no existen sino fotografías muy deficientes, muchas de ellas tomadas en los campamentos, y estos originales no se presentan a ningún género de reproducción ni aún al grabado, porque hay que librar mucho a la inducción del artista para apreciar rasgos y líneas apenas perceptibles y que aceptadas en cualquier sentido que no sea el verdadero, dejará mucho que desear al parecido. ("Prospecto", Álbum, 1893, p. 3)

Las imágenes están incorporadas y reguladas por su imposibilidad de representar un "sentido verdadero" señalando así su pura presencia. Es decir, que simplemente están allí y que la verdad de su representación descansa en la escritura, en el nombre del individuo que un texto le asigna ya que por sí misma dejan mucho que desear "al parecido". ¿Cómo pensar entonces las relaciones iconológicas en el Álbum? ¿Cuál es la economía en funcionamiento entre un texto que dice lo visual y una visualidad que no dice, pero que impone una presencia?

\section{TEXTO E IMAGEN. CONSTRICCIONES}

La textualidad y la visualidad del Álbum de la guerra del Paraguay establecen una economía de constricción mutua. El texto intenta regular la percepción de las imágenes en la lectura, intenta corregirlas, para finalmente prescindir de ellas. Desde el inicio el discurso escrito paradójicamente niega a esta revista ilustrada su naturaleza de medio visual, según se indica en las primeras páginas:

La relación que emprendemos en este álbum es esencialmente gráfica, sin excluir en absoluto la comprobación documentada de los servicios prestados o de los hechos puestos de manifiesto en el retrato o en la lámina (...) la índole de esta publicación no excluye tampoco los trabajos literarios o científicos relacionados con la guerra dentro del vasto campo de su acción, el episodio romancesco, la leyenda popular y el comentario contemporáneo que no comprometen ni afectan la versión histórica. (Álbum, 1893, p. 2)

El enunciado excluido en esta afirmación es que las imágenes sí pueden afectar la comprensión histórica y por eso deben ser corregidas. El "retrato" o la "lámina" se incluyen en el Álbum en tanto estén documentados, tengan la autoridad en la materia o estén firmados: "en cuyo caso cada cual asume la responsabilidad de sus versiones y afrontará seguramente la discusión que pudiera provocar" (1893, p. 2).

La textualidad del Álbum impone que las condiciones de legibilidad de los testimonios de la guerra estén siempre dentro del texto y nunca fuera de él. El intento, nuevamente, no es el de poner a funcionar una interacción fluida entre imágenes y piezas escritas sino más bien el de establecer una no-interacción, establecer una separación y, por momentos, una subordinación de lo visual a lo textual. De este modo puede verse la importancia de las imágenes en un discurso histórico con sentido sobre la guerra: un pequeño error en el diseño, una leve modificación en la imagen, termina por afectar la verdad histórica, ya que determina la construcción del campo visual de la guerra, determina las coordenadas por las cuales la guerra puede ser vista. 


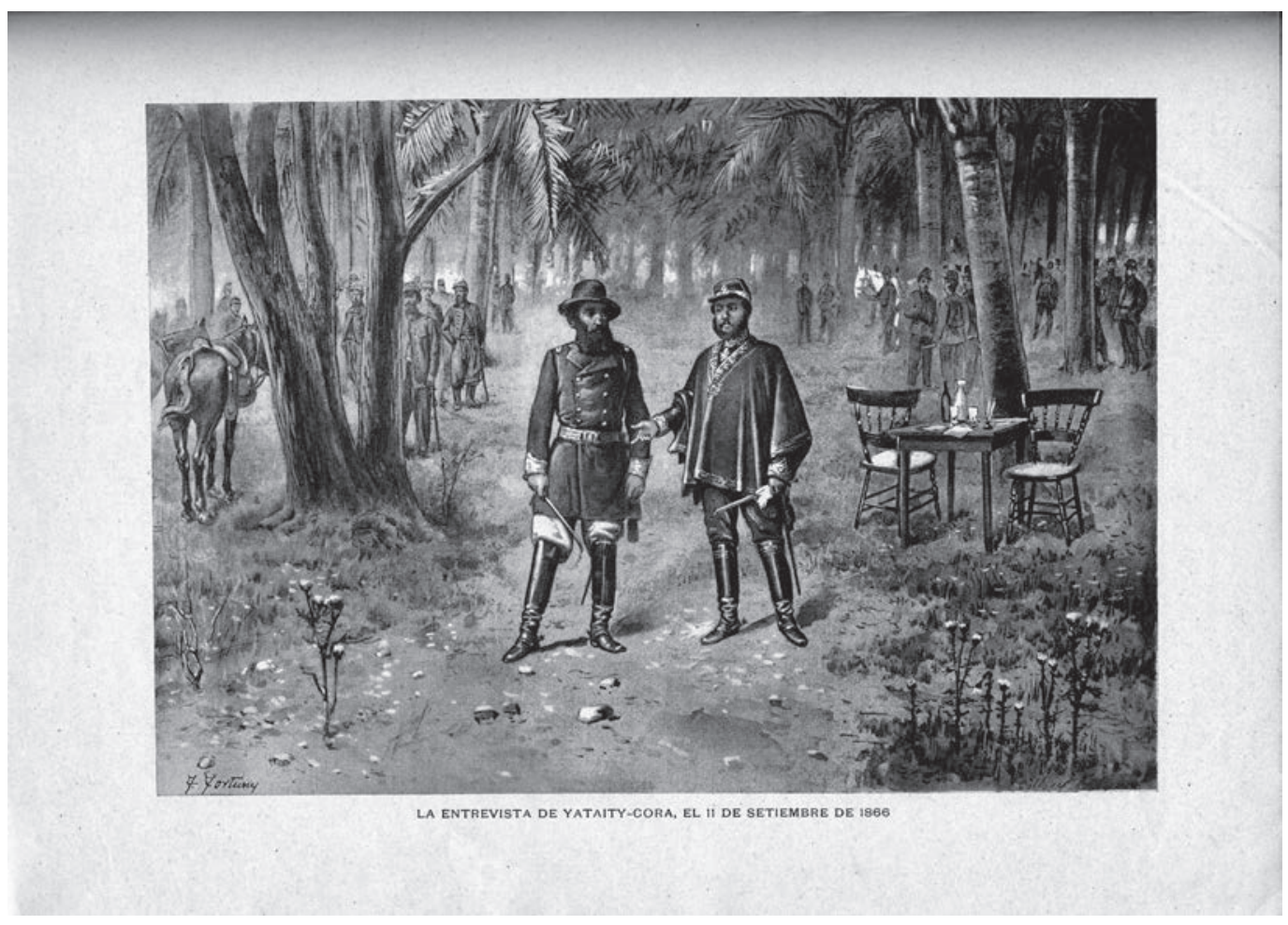

Imagen 6. Álbum de la guerra del Paraguay. "La Entrevista de Yataity-Corá, el 11 de Septiembre de 1866". (anónimo) 1893, p.56.

La nota que acompaña al grabado del "Combate naval del Riachuelo" (imagen 7) que aparece en la primera entrega del Álbum (1893, p. 15) está escrita por Estanislao Zeballos un

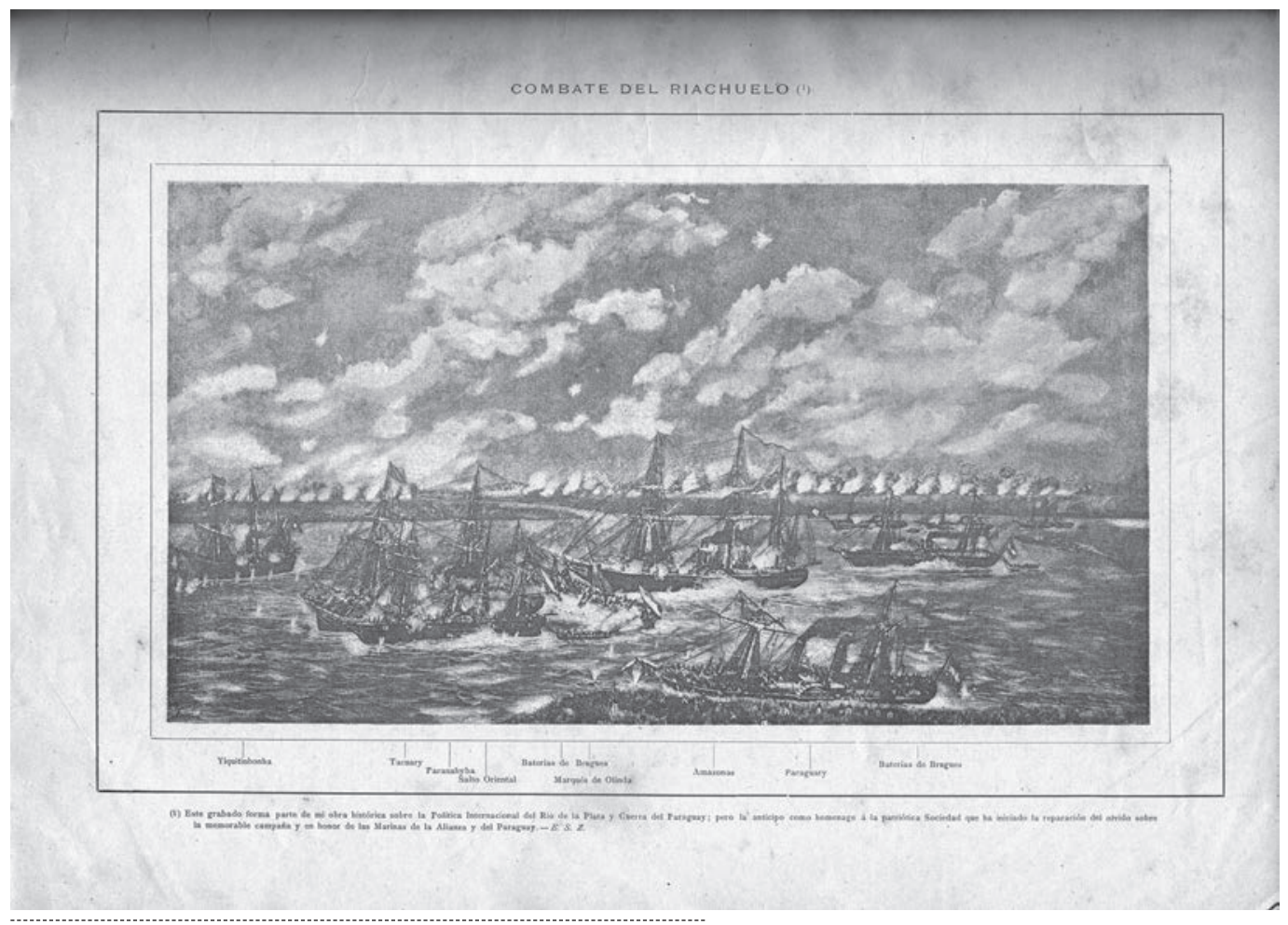

Imagen 7. Álbum de la guerra del Paraguay. "Combate del Riachuelo" 1893, p.15. 
año después de haber dejado su cargo de Ministro de Relaciones Exteriores del país ${ }^{9}$. Zeballos comienza la nota destacando la gran cantidad de representaciones visuales sobre el combate naval del Riachuelo que si bien "representan pintorescamente el combate" son de "escasa información de la verdad histórica" (p. 8). Sigue Zeballos:

(...) se desconoce en ellos, en efecto, la topografía de las barrancas y caracteres del Río Paraná y se aumenta o suprime buques en el momento supremo de la acción (...) en las acuarelas y grabados más comunes falta una nave. (p. 8)

La imagen que presenta el álbum, en palabras de Zeballos, es el único "cuadro auténtico" del combate ya que incluye el barco faltante. Pero a partir de ese momento, el relato comienza a dudar de la representación visual y a prescindir de ella ya que dicha imagen, según el autor, es un "grabado de una copia de una fotografía que se le tomó a una pintura basada en otro grabado previo" (p. 9). La nota continúa haciendo una referencia detallada y minuciosa de los protagonistas del enfrentamiento y termina convirtiéndose en un desfile de nombres de naves y generales. Más allá de este desfile, no hay otro tipo de datos ni estadística alguna de muertos o heridos de ambos lados, ni siquiera hay fechas -nunca se informa al lector cuándo sucedió el episodio, que tuvo lugar el 11 de junio de 1865. Los detalles narrativos del evento no parecen ofuscar tanto a Zeballos, que para el momento de la Batalla del Riachuelo tenía 11 años, como la falta de un barco en otras imágenes del combate. Faltan barcos. La topografía no es correcta y se pierde la acción del combate y entonces el texto comienza a existir para completar esta visión, el texto dice lo visible estableciendo las relaciones iconológicas que van a repetirse a lo largo del Álbum de la guerra del Paraguay.

No obstante, el aislamiento de las imágenes no implica que las formas visuales estén excluidas del texto. Muchas de las imágenes son dichas por el texto o son posibles de ser vistas siempre a través del texto. Me interesaría, sin embargo, resaltar los otros cientos de imágenes que imponen su presencia en las mismas páginas y no son dichas permaneciendo dentro de este régimen de representación en el campo de lo indecible, de lo impronunciable. Existen en el Álbum 411 retratos, de los cuales solo 130 pertenecen a una biografía escrita en la revista. Los 281 retratos restantes dan testimonio de la emergencia de un sistema de representación que "despierta el interés de los lectores" por ser una presencia visual (1893, p. 666).

\section{LA GALERÍA Y EL ÁLBUM COMO REGÍMENES VISUALES}

Existe una silenciosa comunidad de imágenes que da sentido al álbum, transformándolo en una de las más grandes colecciones documentales visuales sobre la guerra. La naturaleza del álbum está determinada simultáneamente por la constricción que la dimensión visual impone al texto en la interacción propia de toda revista ilustrada. Ahora dicha constricción es doble: por un lado se encuentra la "galería" como un modo de expresión y como un espacio de regulación de la mirada y, por otro, aparece en tensión el "álbum" como formato que regula la heterogeneidad visual a través de la colección íntima del acervo privado.

La galería es principalmente un modelo visual o, como sugieren Beatriz González-Stephan y Jens Andermann en Galerías del Progreso, es un "dispositivo óptico de una modernidad emergente" que se convierte quizá en la figura paradigmática en el orden de la cultura visual de fines de siglo XIX (2006, p. 23). La galería organiza una visión del mundo a través del despliegue de imágenes, de lugares y eventos, fenómenos naturales, personas y costumbres de 


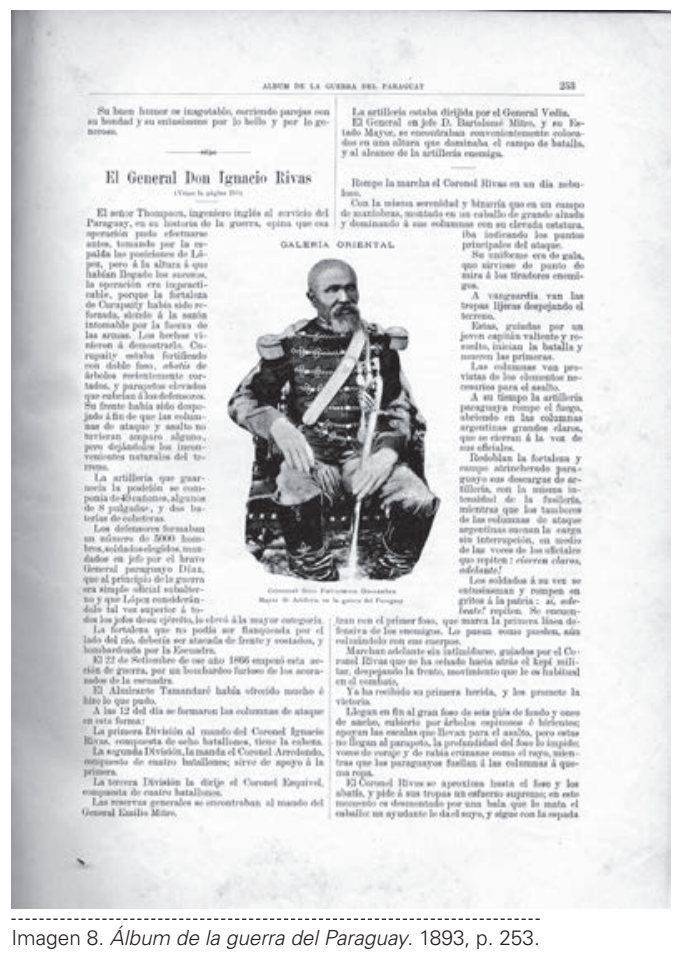

regiones remotas. La naturaleza de la galería es espectacular ya que es un dispositivo pensado para deslumbrar o maravillar al observador al mismo tiempo que muestra una realidad lista para ser vista (la maravilla del espectáculo reside también en el ofrecer una visión). Esto es, como dispositivo de organización y regulación del campo visual, la galería reafirma la naturaleza expositiva y espectacular de su contenido.

Asimismo, la galería estipula las coordenadas de construcción de un discurso histórico específico. El modelo ya había sido utilizado como forma de presentación y exposición del relato histórico en el Río de la Plata en la Galería de celebridades argentinas publicada entre 1857 y 1858. Fabio Wasserman nos indica que la galería era un género textual común en Europa y América para desplegar la historia a través de biografías ilustradas (2008, p. 69). En el caso argentino, para construir dicha galería escrita por múltiples autores se enviaban las litografías de los personajes primero a los distintos escritores y de allí se componían las biografías. La Galería de celebridades marcaba en su disposición iconológica que los retratos litográficos debían preceder a la biografía textual que se iba descubriendo como iluminación de la imagen de la historia. Wasserman observa agudamente que las imágenes parecían ser el verdadero contenido de la galería:

Quizá sea necesario entonces tomar el título de la obra en forma literal y considerar a la Galería como una suerte de museo portátil en el que se pueden contemplar los principales rasgos de algunas figuras prominentes de la vida pública posrevolucionaria. (2008, p. 70)

En efecto, a pesar de que el texto imponía una hegemonía única estableciendo una composición que podía prescindir por completo de las ilustraciones, la Galería de celebridades, no obstante, debía mantener la centralidad de su naturaleza visual para preservar un espacio espectacular capaz de generar una comunidad de sentido para sostener el relato histórico. Si 
bien las imágenes de la Galería de celebridades argentinas existían como presentación y no como representación (el texto las hacía invisibles o suspendía su relevancia), era la presencia de la dimensión visual la que garantizaba y legitimaba un orden que un texto carente de fuentes documentales no podía terminar de dar al relato de la historia. La edición de colecciones documentales "era una práctica erudita pero desligada de un discurso capaz de dotar de sentido al pasado" (Wasserman, 2008, p. 69). De este modo, lo inalterable de las litografías y la inconsistencia del relato escrito en términos de extensión, detalle y calidad de la Galería de celebridades son piezas claves para comprender el lugar de la galería como arreglo visual.

Este es el mismo orden al que el Álbum de la guerra del Paraguay ingresa al ofrecerse a sus lectores a modo de galería. Las imágenes apuntalan la disparidad de los textos que en su mayoría pasan de ser breves a inexistentes, por ejemplo el del teniente general Juan Ayala que aparece en la tapa de la entrega 23 y en la página siguiente a su imagen se señala lacónicamente: "Sin datos especiales, no podemos rememorar sus servicios" (1894, p. 354).

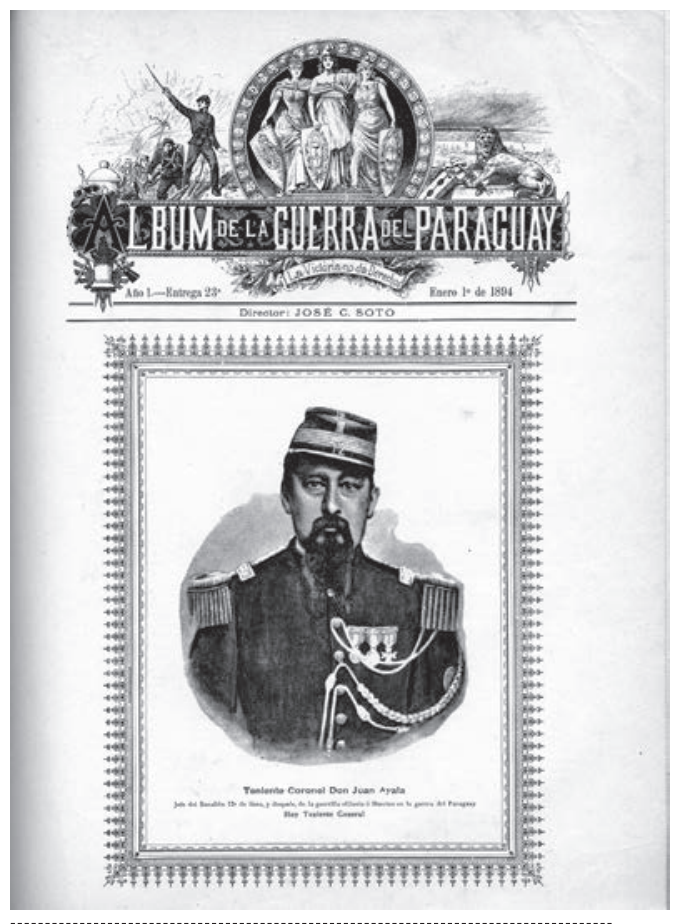

Imagen 9. Álbum de la guerra del Paraguay. Tapa de Entrega 23. 1894 , p. 354.

De aquí la importancia de la galería como espacio de creación de una comunidad visual en la exposición de imágenes; la repetición de ilustraciones de soldados, de rostros y perfiles forja una dinámica visual que termina imponiendo el ritmo a la escritura. Número tras número, el Álbum entrega compulsivamente mínimas biografías de combatientes que sin retrato alguno se suceden para poblar las paredes de la historia de la guerra: en sus 45 ejemplares aparecieron 223 noticias biográficas textuales (130 ilustradas) y 411 retratos de veteranos y caídos en combate (la mayoría litograbados).

Ahora bien, la textualidad y la visualidad de la galería del Álbum de la guerra del Paraguay están también intersectadas por el formato álbum como una nueva dimensión del orden visual 
-el álbum regulando a la galería. El formato álbum era uno de los modos en que circulaban algunos de los periódicos ilustrados durante el XIX. A principios del siglo, el álbum se había consolidado como una forma de tránsito de imágenes de tipos y costumbres. En el Río de la Plata se destacan los trabajos de Essex Vidal (1829), Núñez de Ibarra (1838), d'Hastrel de Rivedoux (1846) y de Juan Carlos Morel (1845), entre otros, que generan una visualidad pública de tradiciones regionales ${ }^{10}$. Sin embargo, a fines del siglo, este formato comienza a hacer referencia a los álbumes fotográficos como espacios de ordenamiento y colección de objetos visuales, respondiendo a lógicas de individuos particulares (Willumson, 2004, p. 63) 11. Me interesa destacar en el Álbum de la guerra del Paraguay esta manera única de coleccionar y de disponer de objetos. Un álbum fotográfico dispone a las imágenes en una colección personal, en una serie cercana a la emoción y sentimiento del sujeto, hecho que puede verse en la revista ilustrada. Cada colección del Álbum de la guerra del Paraguay se manifestaba como única e individual para los veteranos: desde el primer número se ofrecía a los suscriptores que pagaran un cargo extra por una edición de lujo que constaba de una cubierta cromolitograbada con el nombre del suscriptor, transformando así a la revista ilustrada en un bien personal (Álbum, 1893, p. 2). Así, encarnaba fielmente su título en tanto daba a los ex combatientes cientos de retratos de compañeros de armas, abandonados por un texto que no les daba sentido y no distinguía ni celebridad del ignoto, ni la vida de la muerte.

Como régimen visual, el Álbum, en tanto álbum, señala un desfile de presencias heterogéneas. Desde el inicio de la publicación se recurre a la voluntad y entusiasmo de los suscriptores para aportar textos e imágenes, ya con más desesperación desde el número 38 en adelante la revista ilustrada pide a "deudos o conocidos" que envíen los "retratos de los guerreros del Paraguay, y a los que hayan hecho la campaña se sirvan de remitir los suyos a esta dirección" (1895, p. 225). Su plan era cubrir las páginas del álbum con memorias de los participantes de todas las fuerzas:

Aún no ha terminado la galería de retratos de los cuerpos de infantería, faltan las legiones militares que estaban reputadas cuerpo de línea, debiendo seguir en el orden la Guardia Nacional, la Marina, el Cuerpo Médico y la Caballería, sin perjuicio de dar lugar a los retratos retrasados en nuestro poder. (1894, p. 370)

La publicación ilustrada reúne "el mayor número posible de nombres para que se encuentren antes de que se pierda todo" (1895, p. 209). Ante el paso del tiempo (o enfrentado a él) acumula lo dispar y genera un espacio en donde textos e imágenes deshacen sus relaciones de subordinación y su separación que los presentaba como inconmensurables. El álbum como lógica visual no implica la disciplina de un caos iconológico. Por el contrario, es la liberación del orden y la contención de lo que el texto refiere como "otro" y la imagen se rehúsa a conciliar. Es la contención de la fragmentación generada por la violencia de la guerra que desde el pasado le adviene a la revista ilustrada como un presente inevitable. 


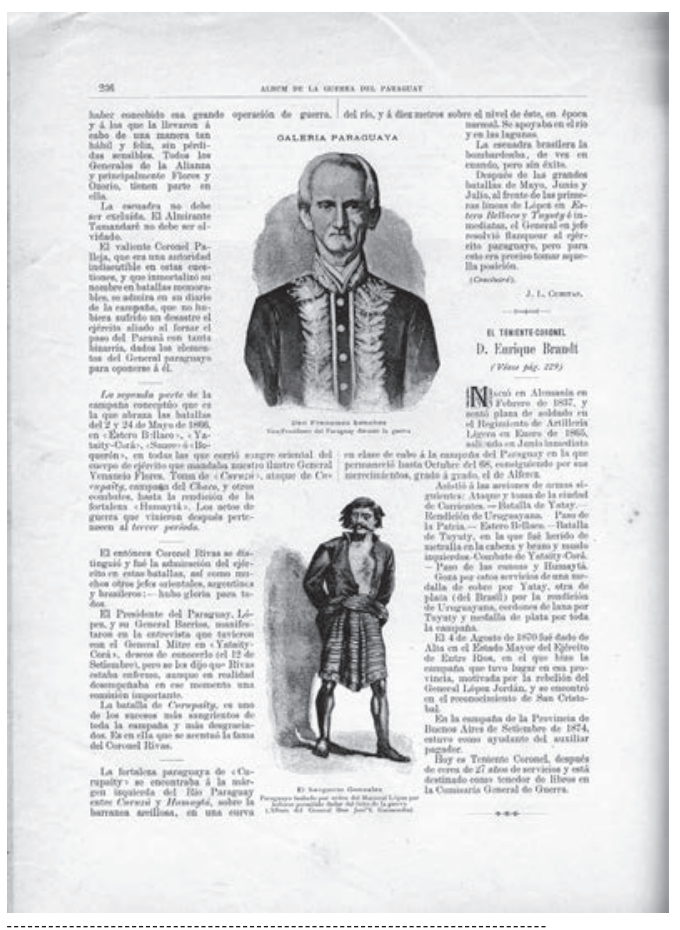

Imagen 10. Álbum de la guerra del Paraguay. 1893, p. 236.

\section{LO IGUALMENTE VISIBLE}

El Álbum de la guerra atesora y da cohesión a imágenes indistintas a la lógica de los ídolos militares, la gloria de los jefes y las figuras que hasta el momento de la publicación eran la clave de lectura de la guerra contra Paraguay. Como señala Liliana Brezzo (2005, p. 2), los primeros textos históricos sobre el conflicto escritos por George Thompson (1869), Jorge Federico Masterman (1870) y Charles A. Washburn (1871) respondían a una razón personalista que explicaba la totalidad del evento como un juego de acciones y reacciones del presidente paraguayo Solano López, separando al mismo tiempo amigos de enemigos y señalando héroes y villanos con grandes nombres y oscuros apellidos. Por el contrario, el Álbum de la guerra formula a través de su arreglo visual una historia signada por el desajuste en las proporciones de la representación jerárquica militar. La repetición de desconocidos, la igualdad de tamaños de los retratos, las contigüidades entre imágenes de generales y soldados rasos, o la insistente presencia de figuras sin relación con el texto, consolidan el camino de una nueva configuración entre lo visible y lo legible de la narrativa bélica de la guerra contra Paraguay. Este sistema de "presencias" dado por la lógica del álbum constituye lo que Rancière llama la visualidad de "lo igualmente visible" (2007, p. 121).

La visualidad de "lo igualmente visible", según establece el filósofo francés en The Future of the Image, ocurre en la novela realista deI XIX como un determinado régimen de representación que es capaz de generar una narración en la que prima la descripción y en la que todos los eventos pierden proporción y jerarquía tornándose "igualmente representables" (2007, pp. 120-121). Rancière toma de Aristóteles la definición de la historia como sucesión de hechos (Kath'ekaston) y la opone a la poética como totalidad orgánica (Kath'olon), afirmando que la "nueva novela" francesa decimonónica subsume la totalidad de la poética a las micro 
percepciones de la descripción histórica produciendo una "igualdad de lo visible" (2007, pp. 121-122). Dos consecuencias le siguen a esta igualdad: en primer lugar, el discurso textual deja de "hacer visibles" los eventos y, en segundo lugar, las imágenes quedan inertes y paralizan la acción (p. 121). Es sugerente que "lo igualmente visible" sea una pieza fundamental para Rancière en la discusión sobre el uso del concepto de lo "irrepresentable" o sobre los "límites de la representación" en el arte (pp. 109-138). Allí, se destaca que muchos de los modos de "irrepresentabilidad" (o espacios de invisibilidad e ilegibilidad), que en general se piensan relacionados con la dimensión traumática del evento que fija los límites del lenguaje sobre la experiencia, en realidad responden a fórmulas narrativas o visuales que históricamente dejan de funcionar o dejan de tener sentido para hablar de temas o eventos (p. 109). Creo que en el caso del Álbum de la guerra del Paraguay las fórmulas arquetípicas utilizadas en las representaciones bélicas de las guerras de independencia y de las guerras civiles en la cuenca del Plata que ocupan la primera mitad del siglo XIX dejan de ser capaces de decir y mostrar la guerra; este nuevo arreglo visual (la galería y el álbum como espacio de lo igualmente visible) es el que señala dicha caducidad.

Desde el punto de vista textual, el discurso sobre la guerra está despojado de la retórica romántica de los héroes y la independencia, y está desplazado a una discusión sobre el progreso y el significado del conflicto para los ex combatientes. A partir del octavo número, la revista ilustrada sale con un nuevo cliché de tapa que indica la posición de los miembros de la Asociación de Guerreros frente a sus pares que lucharon, siguiendo la doctrina de Mariano Varela ante el fin de la guerra: "La victoria no da derechos" (1893, p. 111).

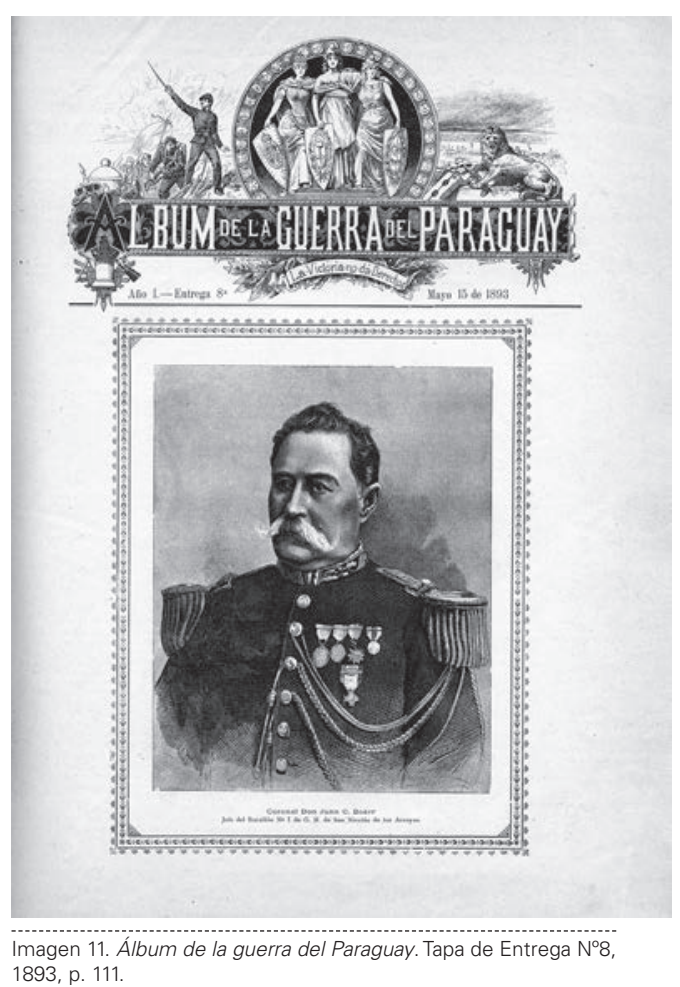

El cliché hace referencia a la editorial de la entrega número dos (1893, p. 17) (imagen 3) titulada "La victoria no da derechos" como una intervención en la formación del derecho in- 
ternacional de la época que tenía como lema "La fuerza prima al derecho". La editorial intenta abrir un espacio de confraternidad entre "veteranos" de guerra de los cuatro países, pero solo entre la "materia prima de la lucha" -los soldados-, alejada de la voluntad política de los países que originaron el conflicto, resaltando el valor paraguayo y dando por concluida cualquier disputa (pp. 17-19). El Álbum no se enfoca en las naciones sino en la comunidad:

De su reunión [de veteranos] surgió la benemérita 'Asociación de Guerreros del Paraguay' con fines de socorro o ayuda para los compañeros porque es una verdad humillante y cruel, que el gobierno argentino no ha aprendido todavía a evitar la desnudez o el hambre del ciudadano que supo dejar sobre las trincheras enemigas el brazo con que ganaba el pan de sus hijos y que, mutilado inválido por la patria, muere de hambre o de vergüenza solicitando una limosna al indiferente que por su lado pasa. (1893 p. 45)

Por otro lado, como ya se ha indicado, desde su despliegue visual el álbum y la galería como arreglo de las imágenes y los textos hacen imposible sostener la monumentalidad del relato visual de la guerra. Este relato estaba generalmente relacionado con las pautas pictóricas de la academia europea o la ya tardía escuela retratística de David, que desenvolvía una poética esencialmente neoclásica semejante a la iconografía centrada en la figura de Napoleón como encarnación de los héroes greco-romanos (Toral, 2001, p. 113) ${ }^{12}$.

A la luz de "lo igualmente visible", se puede pensar el Álbum de la guerra del Paraguay como un régimen en el que el uso de las fórmulas anteriores en el siglo XIX latinoamericano para hablar sobre la guerra han dejado de funcionar (la novela histórica, la épica, la visualidad neoclásica de la pintura académica, la ilustración erudita). Los lugares de visibilidad e invisibilidad, de legibilidad y de ilegibilidad aparecen cuando el lenguaje sobre el evento bélico está liberado de los modos narrativos históricamente utilizados. Es cierto que la publicación utiliza algunas fórmulas y convenciones de la prensa del XIX, ya que es parte del modo de producción propio del siglo en los medios gráficos. Esto va a señalar cierto camino en que la representación toma una forma determinada (la del álbum, la galería o la misma revista ilustrada), una forma aceptada y convencional para la construcción de una colección documental, para la escritura de la historia y la formación del archivo visual. Sin embargo, estas formas visuales que garantizan la legibilidad del contenido del Álbum de la guerra del Paraguay son las que, en definitiva, a través del modo en que hacen "igualmente visibles" a cada una de las partes de la guerra, hacen desaparecer la narrativa épica del conflicto y la monumentalidad visual del evento. El Álbum de la guerra se presenta entonces como un material único en el siglo XIX latinoamericano: el despliegue de una memoria visual colectiva, un ejercicio de lectura que la comunidad de ex combatientes hace de su propio pasado.

\section{NOTAS}

1 La tradición iconológica tiene una larga data. Se puede argumentar que sus inicios se remontan a la lconología de Cesare Ripa (1593), una propedéutica para la creación visual de iconos alegóricos clásicos o instrucciones textuales para la construcción de imágenes. Mi trabajo está enmarcado por teóricos que comenzaron a forjar un campo de trabajo en el siglo pasado identificado como "iconología", como un metadiscurso dentro de la historia del arte en la escuela norteamericana. Uno de los trabajos pioneros sobre iconología es Studies in Iconology, hecho en 1939 por Erwin Panofsky, quien sistematiza ciertos supuestos del trabajo de Aby 
Warburg. Para explorar la relación entre Warburg y Panofsky en profundidad confróntese el excelente ensayo de Silvia Ferretti (1989). La propuesta de Panofsky es la producción de una ciencia discursiva con la que se pueda analizar y hablar sobre las representaciones visuales. Esta definición de iconología está articulada en una teoría de la ideología que postula un "principio unificador" determinado por principios culturales que revelan las actitudes de una nación, periodo, clase social o religión (1989, p. 30). En las páginas de mi trabajo utilizo la redefinición y reconceptualización del término iconología de W.J.T. Mitchell en su trabajo fundamental Iconology: Image, Text, Ideology de 1987, en el cual se establece la posibilidad de que las imágenes puedan construir un discurso sobre ellas mismas: una retórica de las imágenes y una imagen de la retórica. Esta redefinición, que abrió el debate interdisciplinario en la historia del arte, se ve desarrollada en profundidad en Picture Theory (1995), en donde el teórico norteamericano acuña la categoría de metaimágenes (metapictures) que son aquellas que tienen la capacidad de reflexionar sobre su propia naturaleza de imágenes. Así, el teórico norteamericano habla de una icono-grafía, jugando claramente con el término clásico, abriendo la posibilidad de pensar un discurso puramente visual que excluya lo escrito. En este caso la "grafía" es la marca de la imagen misma. Sin embargo, esta icono-grafía, pensada como imágenes mostrándose a sí mismas, no puede existir fuera del discurso escrito, así como el discurso no puede existir fuera de la imagen. Mitchell, de este modo, lleva el argumento al extremo señalando que la interacción entre lo visual y lo textual es "constitutiva" de la representación misma: "All media are mixed media, and all representations are heterogeneous; there are no 'purely' visual or verbal arts" (1995, p. 5). Entonces, la interacción entre lo visual y lo textual no solo se hace necesaria para el análisis de cualquier representación, sino que también se hace inevitable.

2 Para poder trazar este desplazamiento disciplinario en la academia norteamericana, específicamente, puede seguirse la introducción al excelente trabajo de James Elkins (2003) quien brinda una genealogía de los estudios de cultura visual, desde sus relaciones con los estudios culturales y materiales en el Reino Unido hasta la aparición de programas de maestría y doctorado en Estados Unidos.

3 La Asociación fue creada en 1892, un año antes de la salida del Álbum de la guerra del Paraguay. Estaba presidida por el General Joaquín Viejobueno, su vicepresidente primero era el Coronel Juan C. Boer, y el vicepresidente suplente era el Coronel José María Morales. Hoy en día, su labor se ve continuada por la Asociación Argentina de Descendientes de Guerreros del Paraguay.

4 López, Garmendia y Methfessel recibían una paga por sus contribuciones en el Álbum. Para los tres el Álbum representa el primer medio de publicación y publicidad de sus obras. Para un panorama de la circulación de las obras visuales de estos autores durante la guerra y hasta el final del siglo XIX véase los capítulos titulados "La mirada épica" y "La batalla en papel" del trabajo de Cuarterolo Soldados de la Memoria (2000) y el de Toral (2001).

5 Los retratos fueron principalmente tomados en estudios y se trataban de cartes de visite. La carte de visite o tarjeta de visita era un formato comercial inventado por el fotógrafo francés Adolphe Disderi en 1854, de copias de $9 \mathrm{~cm}$ por $5 \mathrm{~cm}$, en algunos casos se encuentra la variante de $10 \mathrm{~cm}$ por $7 \mathrm{~cm}$, un poco más grande que el tamaño de una tarjeta de presentación, de allí su nombre. Se obtenían varias copias al mismo tiempo de un negativo de una cámara que tenía entre 4 a 12 objetivos para capturar la misma imagen. Las cartes de visite abrieron un espacio completamente nuevo en el modo de expresión visual de la época. Su tamaño, su cantidad y su precio permitían una circulación masiva y simultáneamente las convertían en objetos de intercambio. Rápidamente comenzaron a coleccionarse, trocarse y venderse entre un público más amplio que marginaba a las elites intelectuales.

6 Para un análisis histórico sobre la guerra contra el Paraguay pueden revisarse algunos trabajos contemporáneos significativos de una extensísima lista bibliográfica como el de Luc Capdevila (2010), la colección de ensayos de Nicolas Richard (2007) y la de Thomas Whigham (2004). También analizan la guerra dentro de las tensiones de la región Miguel Ángel De Marco (2003), Thomas Whigham (2002), Chris Leuchars, (2002) y el fundamental trabajo de Francisco Doratioto (2002).

7 El Impero del Brasil intervino en cada uno de sus países vecinos durante el siglo. A Uruguay lo incorporó como estado -provincia Cisplatina- entre 1824 y 1828, con Argentina estuvo en guerra entre 1825 y 1828 , participó en la formación del Ejército Grande para derrocar a Juan Manuel de Rosas (1852) en la Batalla de Caseros, y reclamaba territorios en el norte del Paraguay.

8 De una inagotable lista bibliográfica, para este breve recuento de la historia de la guerra sigo los trabajos de Capdevila (2010), Doratioto (2002) y Kraay y Whingham Ed. (2004).

9 Liliana Brezzo (2009) analiza el proyecto histórico de Zeballos y su interés en el Álbum de la guerra como un espacio para hablar de una retórica de "los vencidos" y la recolección de testimonios. 
10 El trabajo de Núñez de Ibarra Trajes y costumbres de la Provincia de Buenos Aires está compilado en El grabador argentino Manuel Pablo Núñez de Ibarra (1782-1862) de Rodolfo Trostiné (1953). Los Trajes y costumbres... eran 24 litograbados y se conocen como "serie chica" por el tamaño de las láminas. La obra más conocida de Adolphe D'Hastrel en el Río de la Plata fue la colección de acuarelas Álbum de La Plata o Colección de las vistas y costumbres del Río de la Plata (1846). Doce litografías coloreadas de este álbum pueden verse en El pintor y litógrafo Francés capitán Adolphe D’Hastrel (1946).

11 Para más datos sobre el álbum durante el final del siglo XIX y su circulación doméstica, además del brillante análisis de Willumson (2004), confróntese los célebres trabajos de Walter Benjamin (1979) y Pierre Bourdieu (2001).

12 La importancia del retrato fotográfico en el Álbum de la guerra y los modos de ordenar el flujo visual (la "galería" y el "álbum") provocado por dichas imágenes sugieren que es también el material visual el que impone los ritmos y las interrupciones en las prácticas representacionales: la guerra contra el Paraguay fue la primera guerra fotografiada en América Latina.

\section{REFERENCIAS}

Achugar, Hugo. "Imágenes fundacionales de la nación". Alteria. vol. XVIII (2008): 215-229.

Andermann, Jens y Gonzalez-Stephan, Beatriz. Galerías del progreso. Museos, exposiciones y cultura visual en América Latina. Rosario: Beatriz Viterbo Editora, 2006.

Asociación Guerreros del Paraguay de la República Argentina. Álbum de la guerra del Paraguay. Buenos Aires: Imprenta de Jacobo Peuser/Taller de tipografía de la Penitenciaría Nacional, 1893-1896.

Benjamin, Walter. "A Small History of Photography". En One-Way Street and Other Writings. London: New Left Books, 1979. Pp. 240-257.

Bourdieu, Pierre. Photography. A Middle-Brow Art. Stanford: Stanford University Press, 2001.

Brezzo, Liliana. "La guerra de la Triple Alianza en la primera persona de los vencidos: El hallazgo y la incorporación de la sección Estanislao S. Zeballos del Ministerio de Defensa del Paraguay". Anuario de la Escuela de Historia. Facultad de Humanidades y Artes, UNR, Rosario. núm. 22 (2009): 217-235.

Brezzo, Liliana. "La guerra del Paraguay a través de la memoria de sus actores: el proyecto historiográfico de Estanislao Zeballos". Ponencia presentada en Le Paraguay à I'ombre de ses guerres. Paris: MAL-EHESS-IEP 17-19, noviembre, 2005. Building Nineteenth-Century Latin America. Re-Rooted Cultures, Identities and Nations, eds. William G. Acree Jr. y Juan Carlos González Espitia. Nashville: Vanderbilt University Press, 2009. 1-10.

Capdevila, Luc. Una guerra total: Paraguay 1864-1870. Ensayo de historia en el tiempo presente. Buenos Aires: Editorail Sb, 2010.

Cuarterolo, Miguel Ángel. Soldados de la memoria. Imágenes y hombres de la guerra del Paraguay. Buenos Aires: Grupo Editorial Planeta, 2000.

De Marco, Miguel Angel. La guerra del Paraguay. Buenos Aires: Grupo Editorial Planeta, 2003.

Doratioto, Francisco. Maldita guerra: nova historia da Guerra do Paraguai. São Paulo: Companhia das Letras, 2002

El pintor y litógrafo francés capitán Adolphe D’Hastrel. Buenos Aires: Imprenta Guillermo Kraft Lt., 1946.

Elking, James. Visual Studies. A Skeptical Introduction. New York: Routledge, 2003.

Escobar, Ticio. Una interpretación de las artes visuales en el Paraguay. Tomo I. Asunción: Centro Cultural Paraguayo Americano, 1982.

Essex Vidal, Emeric. Picturesque IIlustrations of Buenos Ayres and Monte Video, consisting in Twenty-four Views, accompanied with Descriptions of the Scenery, and of the Costumes, 
Manners, \&c. of the Inhabitants of those Cities and their Enviroment. London: B. Ackermann, 1829.

Ferretti, Silvia. Cassirer, Panofsky, and Warburg. Symbol, Art, and History. New Heaven: Yale University Press, 1989.

González-Stephan, Beatriz y Jens Andermann, eds. Galerías del Progreso. Museos, exposiciones y cultura visual en América Latina. Rosario: Beatriz Viterbo Editora, 2006.

González-Stephan, Beatriz y Jens Andermann, eds. "Forms of Historic Imagination: Visual Culture, Historiography, and the Tropes of War in Nineteenth-Century Venezuela". En Building Nineteenth-Century Latin America. Re-Rooted Cultures, Identities and Nations, eds. William G. Acree Jr. y Juan Carlos González Espitia. Nashville: Vanderbilt University Press, 2009. Pp. 101-131.

Kraay, Hendrik y Thomas Whigham (ed.). I Die with My Country. Perspectivas on the Paraguayan War, 1864-1870. Lincoln, NE: University of Nebraska Press, 2004.

Knauss, Paulo. Revistas Ilustradas. Modos de ler e ver no Segundo Reinado. Rio de Janeiro: Mauad, 2011.

Leuchars, Chris. To The Bitter End. Paraguay and the War of the Triple Alliance. Westport, CT: Greenwood Press, 2002.

Masterman, George. Seven Eventful Years in Paraguay. London: S. Low, Son, and Marston, 1870

Mitchell, W.J.T. Iconology. Image, Text, Ideology. Chicago, IL: University of Chicago Press, 1987.

Mitchell, W.J.T. Picture Theory. Essays on Verbal and Visual Representation. Chicago, IL: University of Chicago Press, 1995.

Morel, Juan Carlos. Usos y costumbres del Río de la Plata. Buenos Aires: Librería L'Amateur, $1945,1845$.

Panofsky, Erwin. Studies in Iconology: Humanistic Themes in the Art of Renaissance. New York: Oxford University Press, 1939.

Plá, Josefina. El grabado en el Paraguay. Asunción: ALCOR, 1962.

Plá, Josefina. Las Artes Plásticas en el Paraguay. Breve Esquema Histórico. Buenos Aires: Instituto de Arte Americano e Investigaciones Estéticas de la Facultad de Arquitectura y Urbanismo, 1967.

Rama, Ángel. La ciudad letrada. Hanover: Ediciones del Norte, 1984.

Rancière, Jacques. The Future of the Image. Londo: Verso, 2007.

Richard, Nicolas, ed. Les Guerres du Paraguay aux XIXe et XXe Siècles: Actes du Colloque International le Paraguay à L'ombre de ses Guerres, Acteurs, Pouvoirs et Représentations, Paris, 17-19 Novembre 2005. Paris: CoLibris, 2007.

Ripa, Cesare. Iconologia del Cavaliere. [1593]. s.n.: Nella stamperia di Piergiovanni Costantini, 1767.

Salerno, Osvaldo. "Presentación". En El Centinela. Periódico de la guerra de la Triple Alianza, ed. Ana Sofía Piñeiro. Asunción: Centro de Artes Visuales/Museo del Barro, 1998. s.n.

Salerno, Osvaldo y Ticio Escobar. "El Grabado de Cabichuí como Expresión Popular." En El Cabichuí. Periódico de la guerra de la Triple Alianza. Asunción: Centro de Artes Visuales/ Museo del Barro, 1984. s.n.

Schwarcz, Lilia Mortiz. Retrato em branco e negro: Jornais, escravos e cidadãos em São Paulo no final do século XIX. Rio de Janeiro: Companhia das Letras, 1987.

Schwarcz, Lilia Mortiz. As barbas do Imperador. D. Pedro II, um monarca nos trópicos. Rio de Janeiro: Companhia das Letras, 1998.

Silva Beauregard, Paulette. "Un lugar para exhibir, clasificar y coleccionar. La revista ilustrada como una galería del progreso." En Galerías del Progreso. Museos, exposiciones y cultura visual en América Latina. Rosario: Beatriz Viterbo Editora, 2006. 373-406 
Thompson, George. The War in Paraguay: With a Historical Sketch of the Country and Its People and Notes Upon the Military Engineering of the War. London: Longmans, Green, and Co., 1869.

Trostiné, Rodolfo. El grabador argentino Manuel Pablo Núñez de Ibarra (1782-1862). Buenos Aires: Talleres Gráficos San Pablo, 1953.

Toral, André. Imagens em Desordem. A Iconografia da Guerra do Paraguai. São Paulo: Humanitas/ FFLCH/USP, 2001.

Washburn, Charles. The History of Paraguay: with Notes of Personal Observations and Reminiscences of Diplomacy under Difficulties. Boston : Lee \& Shepard, 1871.

Wasserman, Fabio. Entre el Clio y la Polis. Conocimiento histórico y representaciones del pasado en el Río de la Plata (1830-1860). Buenos Aires: Teseo, 2008.

Whigham, Thomas L. The Paraguayan War. Causes and Early Conduct. Lincoln: University of Nebraska Press, 2004.

Willumson, Glenn. "Making Meaning. Displaced materiality in the library and art museum". En Photographs Objects History. On the Materiality of Images, eds. Edwards, Elizabeth y Janice Hart. New York: Routledge, 2004. 62-80.

\section{Cómo citar este artículo:}

Díaz-Duhalde, Sebastián. “Estudios iconológicos en la prensa ilustrada del siglo XIX. El Álbum de la guerra del Paraguay y la visualidad de "lo igualmente visible"." Cuadernos de música, artes visuales y artes escénicas, 9 (2), 127-146, 2014. http:// dx.doi.org/10.11144/Javeriana.mavae9-2.eipi 